\title{
It's Good to Be the King: Head-Pieces in Ballard Folio Scores
}

\section{Citation}

Cawelti, Andrea. 2014. "It's Good to Be the King: Head-Pieces in Ballard Folio Scores." The Library Quarterly: Information, Community, Policy 84 (2) (April): 209-218. doi:10.1086/675333.

\section{Published Version}

$10.1086 / 675333$

\section{Permanent link}

http://nrs.harvard.edu/urn-3:HUL.InstRepos:23508753

\section{Terms of Use}

This article was downloaded from Harvard University's DASH repository, and is made available under the terms and conditions applicable to Other Posted Material, as set forth at http:// nrs.harvard.edu/urn-3:HUL.InstRepos:dash.current.terms-of-use\#LAA

\section{Share Your Story}

The Harvard community has made this article openly available.

Please share how this access benefits you. Submit a story.

\section{Accessibility}




\section{It's Good to Be the King: Head-Pieces in Ballard Folio Scores}

ohn Milton Ward (1917-2011), a musicologist at Harvard University, amassed a superior collection of primary source material in (inter alia) French opera and ballet, which he donated to the Houghton Library over the course of many years. The cataloging of this collection provided an unusual opportunity to examine many French imprints, particularly those from the lifetime of King Louis XIV of France (1638-1715), in close succession. Some intriguing visual resources appearing in the later full folio scores of Lully operas came to my attention during this project: at a certain point, generic decorative head-pieces evolved into full engravings illustrating specific elements of the operas. What occasioned this change? A deeper examination will provide a few answers.

The Ballard family enjoyed a virtual monopoly on printing music in Paris for almost 400 years. Their first royal patent was granted by King Henri II (1519-1559) in 1552 to Robert Ballard (1530-1588) and his son-in-law Adrien Le Roy (ca. 1520-1598), and then patents were granted in succession to each generation until the second decade of the nineteenth century. The Ballards employed the diamond-shaped movable type music notes designed and cast in the 1550 os by Guillame Le Bé (ca. 1565-1645) right into the eighteenth century, resisting the engraving techniques that were flourishing in Italy and other countries throughout the seventeenth century. Indeed, their monopoly on type printing in France was so tight that it essentially set back the development of French music engraving by a century. Various French engravers who challenged the Ballards were swiftly sued and subdued (Devriès-Lesure 1976, 3). The Ward Collection introduces engraved Ballard scores in 1703, but it was not until the 1740 s that engraving finally became the dominant form of music setting in Paris, significantly behind that of other British and European music publishers. Perhaps because of this situation and its implicit condemnation of the Ballards, and perhaps because other surviving visual source material is compelling, the valuable visual evidence in the first scores engraved by Ballard has

For Jeff Nigro and Jed Wentz, who keep me curious, then always help me find the answers. 
been somewhat overlooked. A brief chronology of pertinent publishing house events will help provide a context to the illustrations.

Around 1650, the theatrical music printed by Ballard took the form of separate part books printed in an octavo format, gradually being replaced by quarto oblong reduced scores. These reduced scores (still printed with that diamond-shaped movable music type without barring) typically included all of the vocal parts but presented the few instrumental parts without any inner voices, often focusing exclusively on the continuo; in sections without singers, only the uppermost string or wind parts were occasionally included.

The family privilege was renewed in 1673 by the king to Christophe Ballard (1641-1715), and it was under Christophe's directorship that "full" scores of operas were first printed, allegedly manifesting all of the vocal and instrumental parts involved in the opera. The popularity (and favor of the king, no doubt) of composer Jean-Baptiste Lully (1632-1687) had presented a perfect opportunity for Ballard to start a line of more luxurious scores, but the king had also granted Lully a separate privilege for the printing and sale of his own music in 1672 . This led in 1680 to a contract between Ballard, Lully, and Lully's librettist Philippe Quinault (1635-1688), delegating Lully's printing rights to Ballard and in return splitting the profits among the three parties until 1702, the duration of Lully's royal privilege (Rosow 1981, 9-10).

In 1679, a partition générale, or "full" folio format, score of Lully's Bellérophon was printed. While the orchestration remained incomplete in this and other full scores to come, these "full" scores were considerably more fleshed out than the aforementioned oblong reduced scores, which continued to be published by Ballard for other operas and ballets. The prologue and each act of this 1679 Bellérophon featured decorative woodcut head-pieces that bore no relation to the subject matter of the opera, as was the style with printed scores and librettos up to this time. Several full scores of Lully operas were printed with similar decorative, visually unrelated head-pieces in the following years. Christophe brought his son into the business upon the latter's marriage in 1698, at which point Jean-Baptiste-Christophe $(1663-1750)$ became an equal director in the firm. But the most important change in Ballard business came in 1707, when Lully's son Jean-Louis (1667-1688) obtained a royal privilege to reprint all of his father's operas (Guillo 2003, 1:66-68). In 1707, the Ballard scores changed in a radical way.

The second edition of Proserpine, printed in movable music type in 1707, featured the usual generic decorative woodcut head-pieces with one startling change: the woodcut at the head of Act 1 features Proserpine's abduction by Pluton (see fig. 1). Alceste, brought out in its second edition in 1708, was fully engraved by Henri de Baussen (active 1685-1720) and included large, act-specific illustrative head-pieces on the prologue and every act, engraved by Gérard Scotin (born 1698) after Jacques Vigoureux Duplessis (before 1680-1732). Duplessis was painter to the Paris Opéra at the time, and as such would have been familiar with the smallest details of Lully's productions. This score of Alceste sets the format for many of the fully engraved scores that would follow, right into the 1720 . 


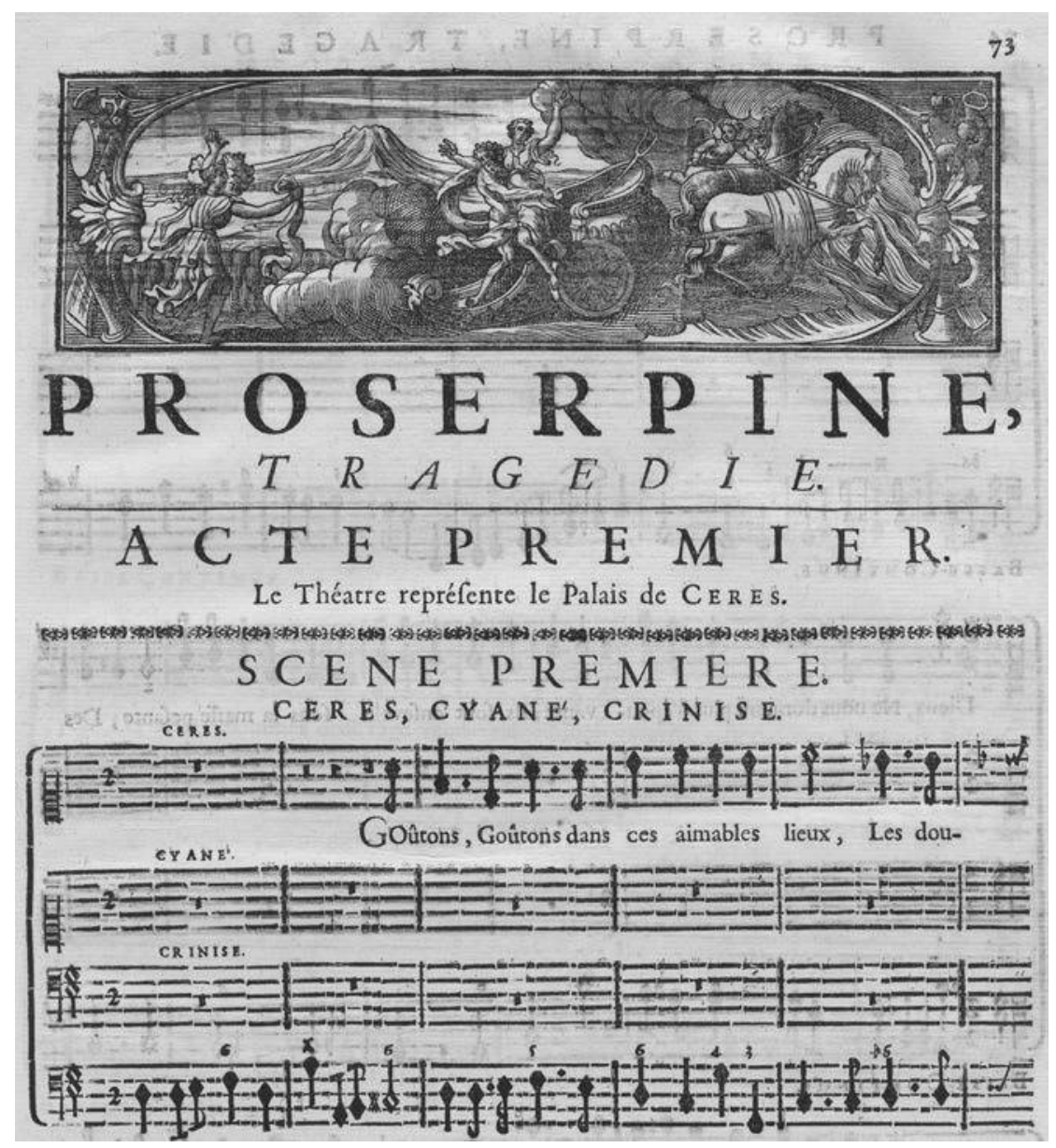

Figure 1. Page 73 from Jean-Baptiste Lully, Proserpine: Tragedie, 2nd ed. (Paris: Christophe Ballard, 1707), M1500.L95 P7 1707. Reproduced by permission of Houghton Library, Harvard University.

The engraved head-pieces are all after the stage settings of Jean Berain (1640-1711), who was responsible for all scene designs, machines, and costumes at the Paris Opéra from 1680 until his death in 1711 (Tollini 2003, 88). While the material available today on Berain's original designs is impressive, these Ballard head-pieces provide the added benefit of showing characters in costume on the stage, illustrating the perspective of the sets and blocking of the characters as well as illuminating contemporary gestures and stance and how the costumes looked on actual bodies. While these must necessarily be considered secondary sources, and despite the inevitable artistic license, a comparison to the surviving Berain set and costume designs shows that the images capture the productions relatively faithfully as they must have looked on stage at the time that the scores were printed. 
Additionally, these head-pieces, along with (to a lesser extent) the frontispieces in librettos printed throughout this period, illuminate an equally noteworthy phenomenon: the lengths to which these publications, and the productions on which they were based, magnify the grandeur of the king and his surroundings. Not new under Louis XIV, earlier Italian opera designers often set their prologues in a recognizable contemporary setting in order to pay homage to a king, members of royalty, an event, or others paying the bills (La Gorce 1996, 136). Beginning with the designs of Carlo Vigarani (1622 or 1623 to ca. 1713), operas produced under Louis XIV brought this concept to a high art. By the time Berain became designer to the king in 1680, making scenic reference in several acts to a favorite palace, or in some cases even the location where the opera was first created, was standard fare. Since most of the Lully operas were first performed at Versailles, Saint Germain-en-Laye, or the Paris Opéra in the Palais Royal, the iconography of these palaces and gardens came to permeate the scene designs.

Louis is known to have used spectacle as a careful weapon in his diplomatic and domestic arsenals, and reinforcing his court as the center of the world in productions of opera and ballet would have appealed to him: indeed, this probably had been set as such by his order. How better to remind the court and its visitors of just who is the best king? Berain and the Ballards alike would have been quick to obey. These head-pieces give us a glimpse into that complex relationship between performance, courtly iconography, and the experience of that courtly iconography by its audience. Do these head-pieces represent the reality of the performances or an idealized version? As Mel Brooks would say, "It's good to be the king," and perhaps therein lies the answer: maybe it is both. An examination of five representative headpieces will be instructive.

Proserpine was first performed at Saint Germain-en-Laye, February 3, 1680, and it was first printed in score by the Ballards in the same year. The second edition, the next printed, is printed in movable music type and the head-pieces are all standard decorative woodcuts with the exception of this head-piece for the first act (see fig. 1 on the prior page). Also a woodcut, it illustrates the abduction of Proserpine, which actually occurs in the second act, perhaps as the most recognizable scene of the story. No signature or cypher appears in this woodcut, and its style is different enough from the signed decorative woodcuts seen elsewhere in the score to suggest a different artist. Two variant frontispieces identified in-plate as engraved by Jean le Pautre (1618-1682) after Berain adorn the several librettos printed by Ballard in 1680. The scene in the foreground of both (though reversed in one) matches these details for the costumes, chariot, horses and cupid figure, bident, and trailing woman (or women). However, the mountain background seen here matches only one of the frontispieces. The reversed libretto variant illustrates a garden colonnade in the background. The opera was performed at the Paris Opéra on the fifteenth of November. Do these different backgrounds represent different productions, or was the original concept changed at the last minute? 
First performed at the Paris Opéra on February 15, 1686, and first printed in score by the Ballards in that year, Armide was printed in a second engraved edition in 1710 with illustrated head-pieces, followed by another issue of the second edition in 1713. This 1718 headpiece (fig. 2) by engraver Louis Desplaces (1682-1739) after Duplessis was struck from the same plate used in the 1710 edition. In this dramatic head-piece to the final act, after invoking demons to destroy her palace, Armide flees in her dragon chariot. The top of the set is cut off, preventing a comparison with the palace dome so prominent in Berain's original design

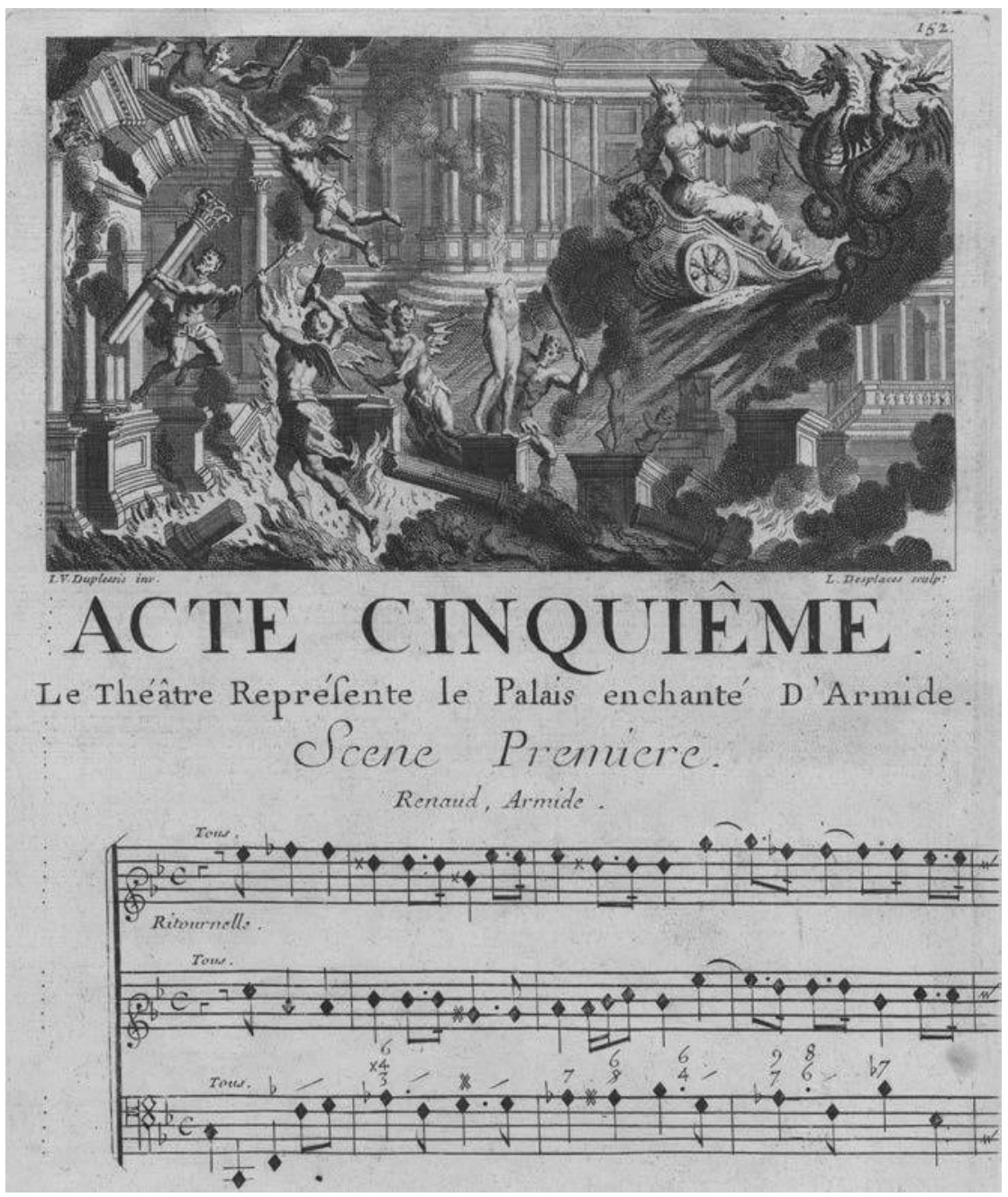

Figure 2. Page 152 from Jean-Baptiste Lully, Armide: Tragedie, 2nd ed. (Paris: Jean-Baptiste-Christophe Ballard, 1718), M1500.L95 A7 1718. Reproduced by permission of Houghton Library, Harvard University. 
(reproduced in La Gorce 1986, 89), but one can clearly see the same classical temple with Ionic column capitals, following the same contour on the floor plan. The demons' costumes and blocking, as well as the details of the dragon cart, seem quite specific, and one assumes that the slight differences from the original design represent the reality of the production as it was last presented in November of 1703 (La Gorce 1992, 201). Armide's wand is also worthy of note, as props are rarely specified in costume designs of the time: here we can see its relative size and length. Wands and staffs provide a visual reference to the particular powers employed by a sorceress: other head-pieces picture enchantresses with the caduceus, the symbol of Hermes, and appropriately, that of alchemy. Note also the smoke and fire (how they were represented at the time) as well as the tumbling set pieces: quite the finish.

Thésée was first performed at Saint Germain-en-Laye on January 15, 1675, and first printed in score by the Ballards in 1688. The 1711 engraved second edition was the next to be printed. The music was engraved by De Baussen, and the head-pieces were engraved by Scotin after Claude Gillot (1673-1722). This head-piece from the fourth act (fig. 3) shows Thésée, Eglée, and Médée (at far right with the wand) during the scene on an enchanted island in which Æglée is forced by Médée to renounce Thésée. The simple wilderness set is likely based on royal gardens, but more interesting in this illustration is the opportunity to examine the costumes and stance in detail. Thésée stands in the open fourth position (based on Baroque dance positions) favored by actors and opera singers of the period. Dance was a vital component of Lully's operas, and while this costume would provide Thésée with the necessary freedom for the intricate footwork required (and with those muscled calves, the strength!), most likely professional dancers would have performed the most demanding of the ballets. His costume would simply echo those of the professional dancers. The skirts of the ladies also provide a subtle but important visual detail: Æglée's skirt falls quite straight and properly to the ground, in sharp contrast to the skirts of Médée, which roil around her. Proper comportment was a vital component of a courtier's image, particularly under stress. Any signs, as we have here in the skirts of Médée, that one's passions were ruling would be noticed immediately and recognized for their implications: Æglée is to be considered the superior of Médée. Médée's wand, as with Armide's, is also of note. Additionally, the hands of the characters provide contemporary gestural details, particularly in the women. Médée's wand hand shows her two middle fingers together, as does the upstage hand of Æglée. Pointing imperiously at Æglée with lowered head, Médée imposes her will. Taken as a whole, there is a great deal of information imparted here that cannot be found in set or costume designs.

Alceste was first performed at the Paris Opéra on January 19, 1674. The libretto (see fig. 4) is the tenth identified by Carl Schmidt (Schmidt 1995, 41) since the first printed in 1674. Several in this sequence of librettos were not printed by Ballard, for whom this actually represents the fourth printing. Frontispieces in librettos during this period could be allegorical 


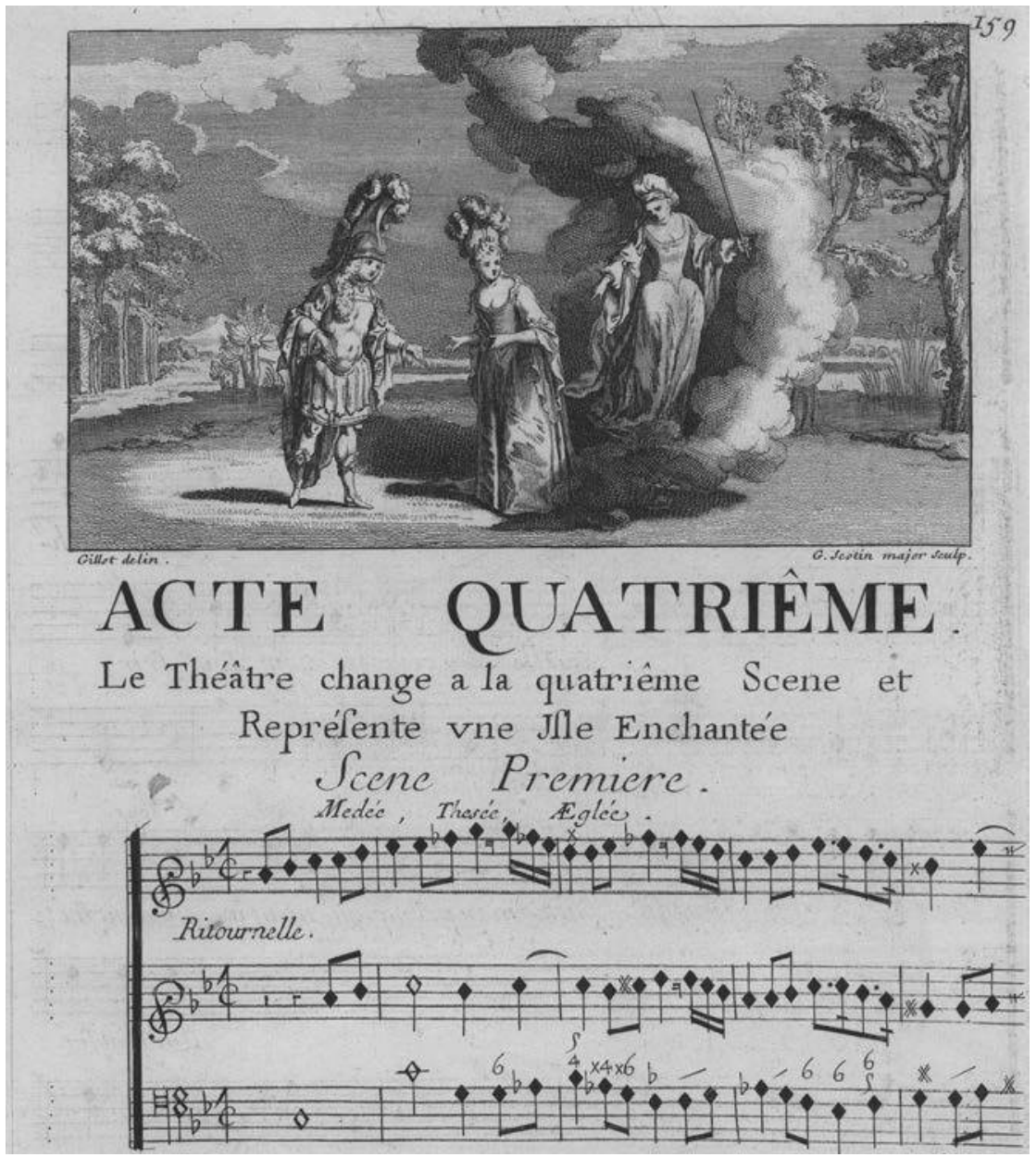

Figure 3. Page 159 from Jean-Baptiste Lully, Thesée: Tragedie, 2nd ed. (Paris: [ Ballard], 1711), M1500.L95 T5 1711 (B). Reproduced by permission of Houghton Library, Harvard University.

or they could include several scenes (as befitting a single image representing an entire opera); however, even these images are worthy of note. Elements of set and costume design are often represented, as well as iconography associated with the king and his court. Many Ballard frontispieces incorporate the crowned three fleur-de-lys coat of arms of the king. In this particular frontispiece, engraved by François Chauveau (1613-1676) and dated in-plate to 1674 , we see a stylized apotheosis of Alceste, possibly combining some elements of set design from the original Vigarani production. The upper section might represent the triumphal arch of the last act, while the lower section suggests the Tuilleries, which used to join the two arms of the 


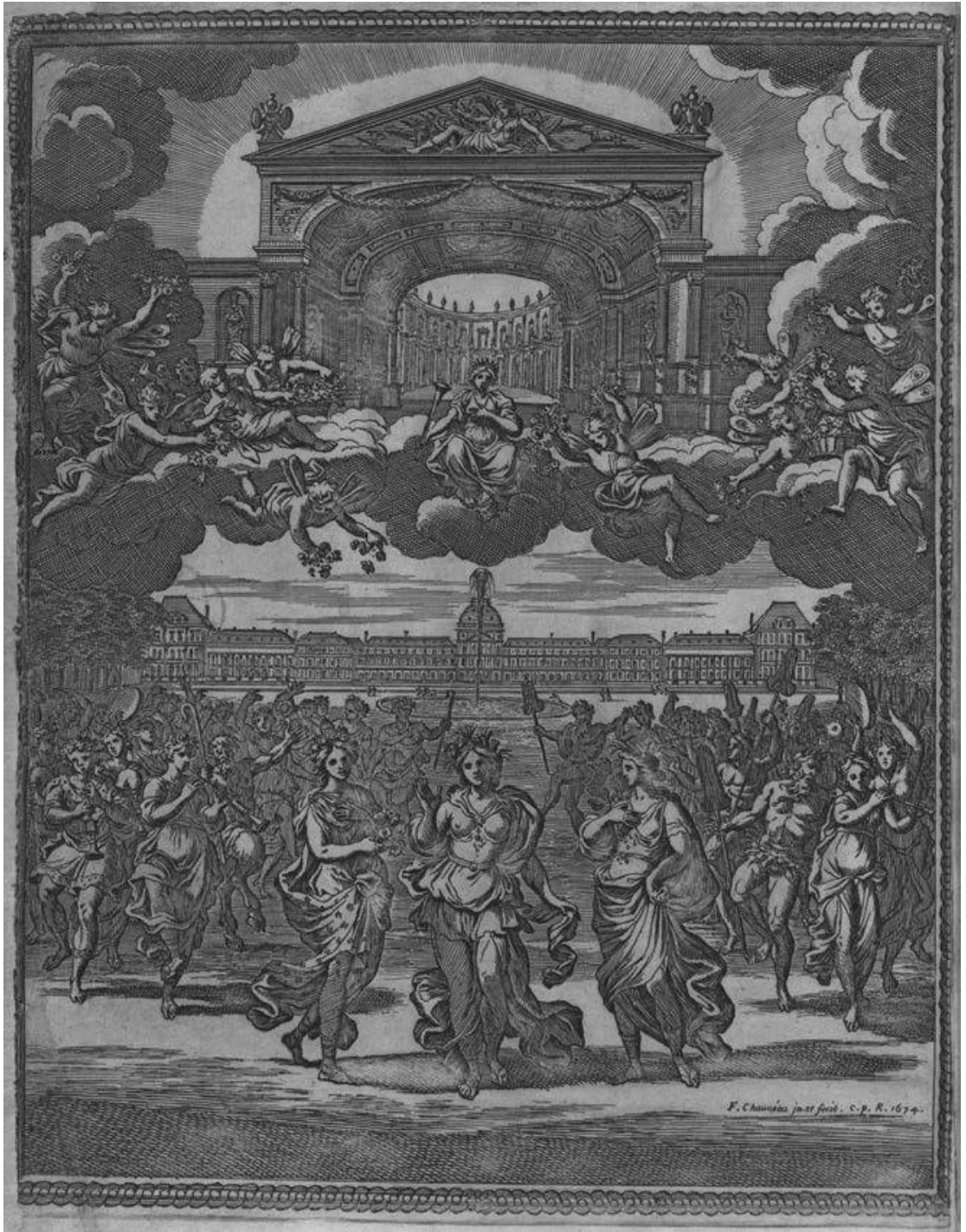

Figure 4. Frontispiece from Philippe Quinault, Alceste, ou, Le triomphe d'Alcide: tragédie representée par l'Academie royale de musique (Paris: Christophe Ballard, 1682), TS 8026.402 1682. Reproduced by permission of Houghton Library, Harvard University.

Louvre Palace. Such blatant visual references to palaces reinforce Louis's court as the epicenter of culture and power.

First performed at Versailles on January 6, 1683 and first printed in score by the Ballards in that year, Phaëton was printed in a second engraved edition in 1709 with illustrated head-pieces, followed by a second issue of the second edition in 1721. This 1721 head-piece 


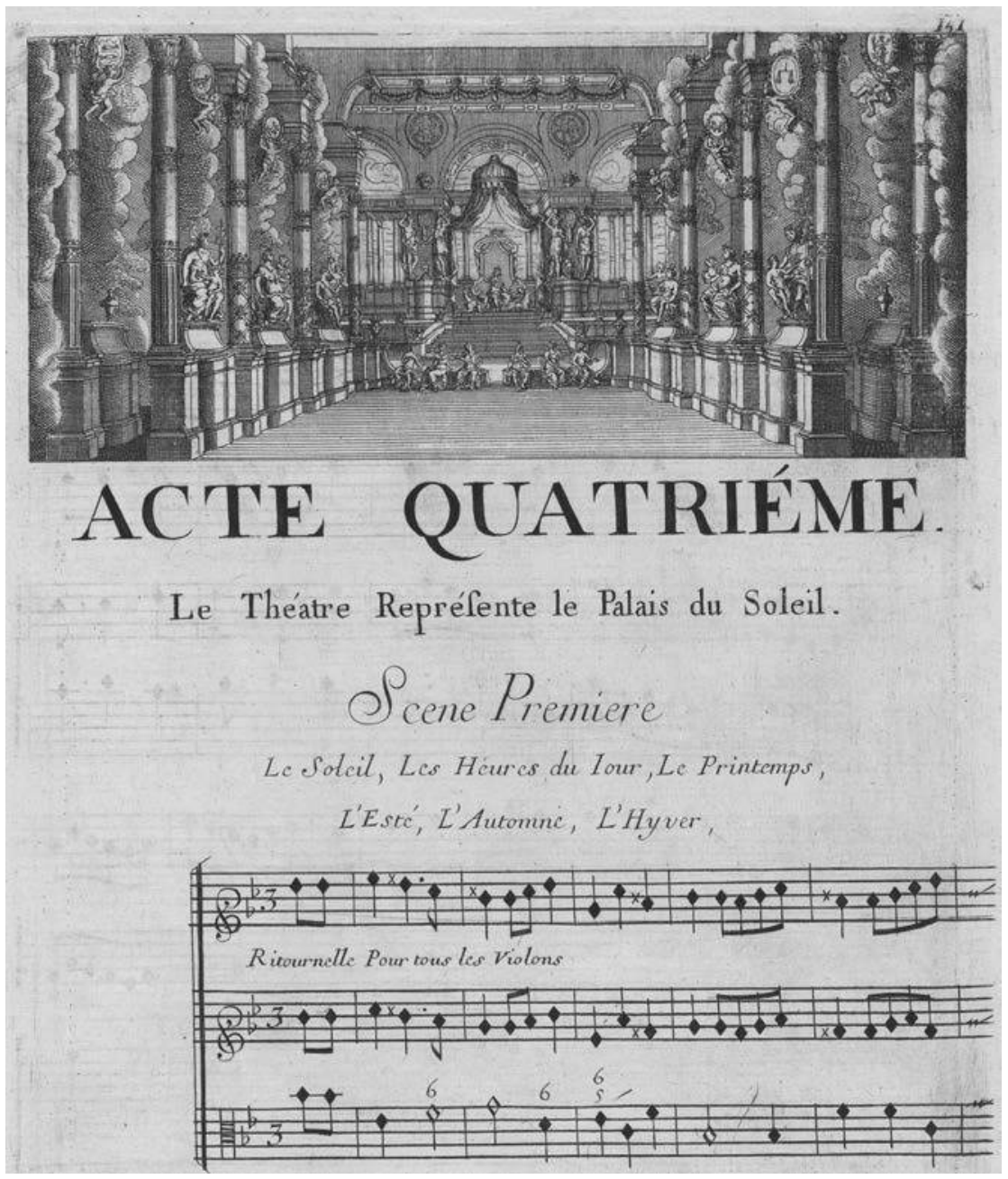

Figure 5. Page 151 from Jean-Baptiste Lully, Phaeton: Tragedie, 2nd ed. (Paris: Jean-BaptisteChristophe Ballard, 1721), M1500.L95 P5 1721. Reproduced by permission of Houghton Library, Harvard University.

(see fig. 5) was struck from the same plate used in the 1709 edition. The head-pieces in Phaëton are unsigned, but they appear to be taken directly from the set designs of Berain: comparison with scans in the Archives Nationales collection of materials related to the Menus Plaisirs du Roi (the department of government administering court festivities and recreation) shows a match to the one head-piece in this score that is also represented in their collection. ${ }^{1}$

1. Archives Nationales. Base de donées. ARCHIM. Menus Plaisirs du Roi. http://www.culture.gouv.fr/documentation /archim/menus-plaisirs.html. 
This fourth act throne room in the Palace of the Sun provides the setting for dances celebrating the upcoming visit of Phaëton. Note the plaques carried by cupids between the column capitals showing signs of the zodiac and other specific set details. The Roi Soleil must have enjoyed the Palais du Soleil. Phaëton was so popular that it came to be known as the "people's opera" (Tollini 2003, 107), and in the head-pieces of the score, we can at last see all of the sets as the audience would have seen them.

\section{References}

Devriès-Lesure, Anik. 1976. Èdition et commerce de la musique gravèe à Paris dans la première moitiè du 18e sieècle: Les Boivin, les Leclerc. Geneva: Minkoff.

Guillo, Laurent. 2003. Pierre I Ballard et Robert III Ballard: Imprimeurs du roy pour la musique, 1599-1673. Sprimont, Belgium: Mardaga.

La Gorce, Jèrôme de. 1986. Berain, dessinateur du Roi Soleil. Paris: Herscher.

La Gorce, Jèrôme de. 1992. L'opèra à Paris au temps de Louis XIV: Histoire d'un thêâtre. Paris: Desjonquères.

La Gorce, Jèrôme de. 1996. "Quelques rapports entre les dessins d'opéras français du règne de Louis XIV et l'architecture, la sculpture et la peinture." In Iconographie et arts du spectacle: Actes du sèminaire CNRS (G.D.R. 712), Paris, 1992, edited by Jèrôme de la Gorce. [Paris]: Klincksieck.

Rosow, Lois. 1981. Lully's Armide at the Paris Opera: A Performance History, 1686-1766. PhD diss., Brandeis University.

Schmidt, Carl B. 1995. The livrets of Jean-Baptiste Lully's tragèdies lyriques: A catalogue raisonnè. New York: Performers' Editions.

Tollini, Frederick Paul. 2003. Scene Design at the Court of Louis XIV: The Work of the Vigarani Family and Jean Berain. Lewiston, NY: Edwin Mellen.

Andrea Cawelti: Ward music cataloger, Houghton Library, Harvard University. Cawelti began her career as an operatic mezzo-soprano. The recipient of numerous prizes and awards, including winning the Met Competition, she has sung with the New York Philharmonic, the New York City Opera, and the Columbus Symphony, among others. An abiding interest in the history of musicians led her to work at the New York Public Library Music Division and the Rosenthal Archives of the Chicago Symphony Orchestra. After retiring from singing, she became the Ward cataloger for the Loeb Music Library and then for the Houghton Library at Harvard University. E-mail: cawelti@fas .harvard.edu. 